\title{
Earnings growth of Mexican immigrants: new versus traditional destinations
}

\author{
Neeraj Kaushal ${ }^{1 *}$ and Ce Shang ${ }^{2}$
}

\author{
* Correspondence: \\ nk464@columbia.edu \\ ${ }^{1}$ School of Social Work, Columbia \\ University, 1255 Amsterdam \\ Avenue, New York, NY 10027, USA \\ Full list of author information is \\ available at the end of the article
}

\begin{abstract}
We study the earnings of Mexican immigrants in their traditional and newer destinations in the US. Analysis based on longitudinal data suggests that during 2001-2009, the real wage of Mexican immigrants increased 1-2\% a year at the traditional destinations, but remained mostly statistically insignificant at the newer destinations. Mexicans at the traditional destinations exhibited greater residential stability: internal migration, non-follow up in the longitudinal data, and predicted return migration were higher among immigrants at the newer destinations than among immigrants at the traditional destinations. Predicted return migration was found to be selective on past earnings among men, but not among women. For men, a 10 percentage point increase in predicted probability of return migration was associated with a $0.3-0.5 \%$ lower wage in the year prior to return.
\end{abstract}

\section{Introduction}

The United States has experienced an unprecedented geographic dispersion of Mexican immigrants in last two decades (Massey 2008). Since 1990, Mexicans have migrated to states such as North Carolina, Georgia, Tennessee, Nevada, Utah, Oregon, and Wisconsin, which not only had a negligible presence of Mexican immigrants at that time but also had never received immigrants from any country in significant numbers. In 1990, 85\% of the immigrants from Mexico lived in just three states: California, Texas, and Illinois. By 2010, this proportion fell to $57 \%$. News media, almost on a daily basis, report the travails of Mexican immigrants in the new destinations and how residents, local communities, and state governments are responding to the immigrant influx. However, there are no national-level studies of the selection (entry-level characteristics) and earnings growth of Mexican immigrants in the newer versus traditional destinations.

The objective of this paper is to use nationally representative cross-sectional and longitudinal data to investigate the selection pattern and earnings growth of Mexican immigrants at the newer and traditional destinations. A unique contribution of this paper is to predict the probability of return migration of Mexican immigrants, and investigate if predicted return migration is influenced by past US earnings. Our study of these three inter-related processes - selection, earnings assimilation, and return migration - is likely to provide a more thorough understanding of Mexican immigration than studies that have focused on only one or two of these processes.

Mexican immigrants have a growing and critical presence in the US economy. As of 2008 , they constituted $6 \%$ of the country's working-age population and $23 \%$ of the 
working-age population without a high-school degree ${ }^{1}$. They are the most disadvantaged in terms of education, earnings, and legal residence status in the US (Duncan et al. 2006; Passel and Cohn 2009; Ramirez 2004; and Rumbaut 2006). Previous research has found that Mexican immigrants experience much slower convergence in earnings than other immigrant groups causing fears that Mexican immigrants may be becoming the new underclass (Blau and Kahn 2007; Borjas and Katz 2007; Lazear 2007). These studies used Census data from 2000 or earlier years and did not distinguish between Mexican immigrants living in newer versus traditional destinations ${ }^{2}$. We use more recent data and study entry level earnings and earnings growth at traditional and newer destinations. In addition, our analysis also addresses some of the key weaknesses in previous research. For instance, previous research on Mexican earnings assimilation is based on repeated cross-sectional data, and does not adjust for potential bias on account of selection in immigration and emigration (see discussion in Borjas 1994) ${ }^{3}$.

We address this issue in a number of ways. First, in the cross-sectional analysis, we compare the earnings of Mexican immigrants who arrived in the US during the same period but settled in newer versus traditional destinations after controlling for a rich set of variables including the period of arrival, age at arrival, and year of observation. The cross-sectional analysis thus provides estimates of the relative earnings of Mexicans at different destinations at any single point in time since immigration.

Second, we use longitudinal data to study earnings growth. This analysis includes person-fixed effects to eliminate bias resulting from return migration. Finally, we predict the probability of return migration of Mexicans and investigate if the predicted propensity to return differs by destination and if it is associated with the lagged earnings (earnings prior to return).

\section{Background and theoretical framework}

Historically, new immigrants have followed earlier arrivals from the same country. Living in co-ethnic communities provides access to and information about the local labor, housing, and credit markets. Social networks and cultural and linguistic affinity with the community also help the migration process (Amuedo-Dorantes and Mundra 2007; Aguilera and Massey 2003; Munshi 2003; Zhou and Logan 1989).

Until 1990, the migration pattern from Mexico to the US was typical of the historical trend - with $89 \%$ of all Mexican immigrants settling in four states- California, Texas, Illinois and Arizona ${ }^{4}$. Over the past two decades, however, Mexican immigrants have displayed unprecedented geographic dispersion ${ }^{5}$. Researchers have expounded several theories to describe this phenomenon. Massey (2008) argues that the initial change began with California becoming a less attractive place for Mexicans due to a series of state and federal policy changes including Proposition 187 that barred undocumented persons from utilizing public services, and the tightening of the US-Mexico border that diverted Mexican immigrants from California to other border states. Card and Lewis (2007) found that county-level demand pull factors and city-level supply push factors were significant predictors of Mexican immigrant inflows. Kaushal and Kaestner (2010), on the other hand, found that economic factors were only weakly associated with the geographic dispersion of Mexicans. 
The choice of destination is not random (Borjas 1994). Immigrants move to new destinations because they expect the economic and noneconomic benefits of migration, net of costs, to be higher at the newer destinations than at the traditional ones. Because newer destinations provide fewer ethnic amenities and limited co-ethnic support, immigrants would move to these destinations only if net economic benefits compensate for the loss of network externalities. Massey (1987) argues that immigrants become less positively selected with each successive wave of immigration as expanding networks help reduce the risk of migration.

In short, due to these various selection factors, the initial expected wage of immigrants should be higher at the newer destinations than at the traditional ones. However, it is not clear how earnings will grow over time. At the newer locations, immigrants are more likely to develop US-specific skills (e.g. English language proficiency) since the demand for ethnic skills (to produce goods and services for Mexican immigrants) would be lower at these newer destinations and the demand for US-specific skills higher. Acquisition of US-specific skills will improve eligibility for better paid jobs, facilitating assimilation. Community support and network externalities at traditional destinations also increase assimilation. The relative earnings growth at traditional versus newer destinations will therefore depend on network externalities, post-migration investments in skill development as well as relative opportunities at these destinations.

Immigration to the newer destinations is more likely to be for economic factors and less likely to unite with the family since by definition these destinations have fewer Mexicans (family members) who arrived in earlier cohorts. If so, compared to Mexicans at the traditional destinations, those at the newer destinations face lower costs (economic and non-economic) of return and internal migration, and thus they will have a higher propensity to return to Mexico or move within the US.

In the empirical analysis, we test these hypotheses with regard to immigrant selection, earnings growth, and return migration. A comprehensive analysis of these inter-related processes is critical to understand the earnings assimilation of Mexicans in the US.

\section{Traditional and new destinations}

We divide Primary Metropolitan Statistical Areas (PMSA) in three categories based on vintage Mexican presence in PMSA population and their growth during the 1990s. PMSAs with at least 4\% of the population born in Mexico (Mexican density) in 1990 are defined as traditional destinations. The non-traditional PMSAs are further divided into two groups: new high-growth destinations and low-growth destinations. New high-growth destinations are non-traditional PMSAs with at least $4 \%$ population born in Mexico in 2000. New low-growth destinations are non-traditional PMSAs with less than $4 \%$ Mexican density in 2000.

Table 1 provides the list of traditional and new high-growth destinations with Mexican density levels. The traditional destinations for Mexicans - 27 PMSAs - are mostly located in the southwest and include several PMSAs in California, New Mexico, Arizona, and Texas and one PMSA (Chicago) in the Midwest. Overall, 8\% of the population in these PMSAs was from Mexico in 1990; it rose to $11 \%$ in 2000 and 13\% by 2007-2009. There are 21 new high-growth destinations where Mexican population density rose from $3 \%$ in 1990 to $6 \%$ in 2000 and further to $9 \%$ by $2007-2009$. Our analysis includes 
Table 1 Proportion of PMSA population born in Mexico

\begin{tabular}{|c|c|c|c|c|c|c|c|}
\hline PMSA & $1990^{\mathrm{a}}$ & $2000^{a}$ & $\begin{array}{l}2007 / \\
09^{\mathrm{b}}\end{array}$ & PMSA & $1990^{\mathrm{a}}$ & $2000^{a}$ & $\begin{array}{c}2007- \\
09^{b}\end{array}$ \\
\hline \multicolumn{4}{|l|}{ Traditional destinations } & \multicolumn{4}{|l|}{ New high growth destinations } \\
\hline California, non CBSA area & 0.061 & 0.105 & 0.124 & Arizona, non CBSA area & 0.039 & 0.055 & 0.108 \\
\hline Bakersfield, CA, MSA & 0.080 & 0.126 & 0.167 & Nevada, non CBSA area & 0.025 & 0.045 & 0.066 \\
\hline Brazoria, TX, PMSA & 0.057 & 0.100 & 0.109 & New Mexico, non CBSA area & 0.026 & 0.046 & 0.054 \\
\hline $\begin{array}{l}\text { Brownsville-Harlingen-San } \\
\text { Benito, TX }\end{array}$ & 0.220 & 0.244 & 0.255 & Washington, non CBSA area & 0.017 & 0.041 & 0.062 \\
\hline El Paso, TX, MSA & 0.176 & 0.214 & 0.251 & Albuquerque, NM, MSA & 0.023 & 0.047 & 0.062 \\
\hline Fresno, CA, MSA & 0.101 & 0.151 & 0.153 & Austin-San Marcos, TX & 0.028 & 0.071 & 0.075 \\
\hline Las Cruces, NM, MSA & 0.139 & 0.178 & 0.128 & Boulder-Longmont, CO, PMSA & 0.012 & 0.059 & 0.067 \\
\hline $\begin{array}{l}\text { Los Angeles-Long Beach, } \\
\text { CA, PMSA }\end{array}$ & 0.133 & 0.162 & 0.158 & Denver, CO & 0.012 & 0.059 & 0.062 \\
\hline $\begin{array}{l}\text { McAllen-Edinburg-Mission, } \\
\text { TX, MSA }\end{array}$ & 0.237 & 0.286 & 0.277 & Fort Worth-Arlington, TX, PMSA & 0.030 & 0.067 & 0.114 \\
\hline Merced, CA, MSA & 0.113 & 0.165 & 0.175 & Greeley, CO & 0.033 & 0.077 & 0.071 \\
\hline Modesto, CA, MSA & 0.072 & 0.113 & 0.149 & Las Vegas, NV-AZ & 0.026 & 0.087 & 0.088 \\
\hline Odessa-Midland, TX, MSA & 0.072 & 0.077 & 0.082 & Naples, FL & 0.005 & 0.059 & 0.089 \\
\hline Orange County, CA, PMSA & 0.099 & 0.137 & 0.147 & Oakland, CA, PMSA & 0.031 & 0.072 & 0.072 \\
\hline $\begin{array}{l}\text { Riverside-San Bernardino, } \\
\text { CA, PMSA }\end{array}$ & 0.074 & 0.120 & 0.161 & Phoenix-Mesa, AZ & 0.036 & 0.094 & 0.106 \\
\hline Salinas, CA MSA & 0.130 & 0.196 & 0.232 & Reno, NV & 0.039 & 0.068 & 0.086 \\
\hline San Antonio, TX, MSA & 0.059 & 0.076 & 0.094 & Salem, OR & 0.029 & 0.077 & 0.091 \\
\hline San Diego, CA, MSA & 0.077 & 0.106 & 0.136 & $\begin{array}{l}\text { San Luis Obispo-Atascadero } \\
\text {-Paso Robles, CA }\end{array}$ & 0.031 & 0.050 & 0.051 \\
\hline San Jose, CA, PMSA & 0.050 & 0.084 & 0.099 & Santa Fe, NM & 0.018 & 0.053 & 0.048 \\
\hline $\begin{array}{l}\text { Santa Barbara-Santa Maria- } \\
\text { Lompoc, CA }\end{array}$ & 0.089 & 0.137 & 0.208 & Santa Rosa, CA & 0.034 & 0.076 & 0.063 \\
\hline Stockton-Lodi, CA, MSA & 0.066 & 0.102 & 0.104 & Vallejo-Fairfield-Napa, CA & 0.030 & 0.070 & 0.106 \\
\hline Tucson, AZ, MSA & 0.052 & 0.076 & 0.097 & Waco, TX, MSA & 0.025 & 0.043 & 0.037 \\
\hline Ventura, CA, PMSA & 0.088 & 0.130 & 0.141 & & & & \\
\hline $\begin{array}{l}\text { Visalia-Tulare-Porterville, CA, } \\
\text { MSA }\end{array}$ & 0.129 & 0.185 & 0.162 & & & & \\
\hline Yolo, CA, PMSA & 0.052 & 0.094 & 0.143 & & & & \\
\hline Chicago, IL, PMSA & 0.050 & 0.072 & 0.073 & & & & \\
\hline Laredo, TX, MSA & 0.245 & 0.292 & 0.284 & & & & \\
\hline Texas, non CBSA area & 0.043 & 0.058 & 0.061 & & & & \\
\hline $\begin{array}{l}\text { Total - Traditional } \\
\text { destinations }\end{array}$ & 0.079 & 0.111 & 0.127 & $\begin{array}{l}\text { Total - New high-growth } \\
\text { destinations }\end{array}$ & 0.025 & 0.061 & 0.087 \\
\hline $\begin{array}{l}\text { Total - New low growth } \\
\text { Destinations }\end{array}$ & 0.002 & 0.009 & 0.015 & & & & \\
\hline
\end{tabular}

aased on the 1990 and 2000 Census. ${ }^{b}$ Based on monthly outgoing rotation of CPS 2007-2009.

169 low-growth destinations, where Mexican population density was $0.2 \%$ in 1990, $0.9 \%$ in 2000 and $1.5 \%$ in $2007-2009$. We have elected to keep this category as $45 \%$ of recent Mexican immigrants (in the US for 5 years or less) and 33\% of all Mexican immigrants in our sample lived in these low-growth destinations.

Figure 1 plots Mexican immigrant density at the three destinations. In 1990, 81\% of all Mexicans in the US lived in the traditional PMSAs. Over the next two decades, a 


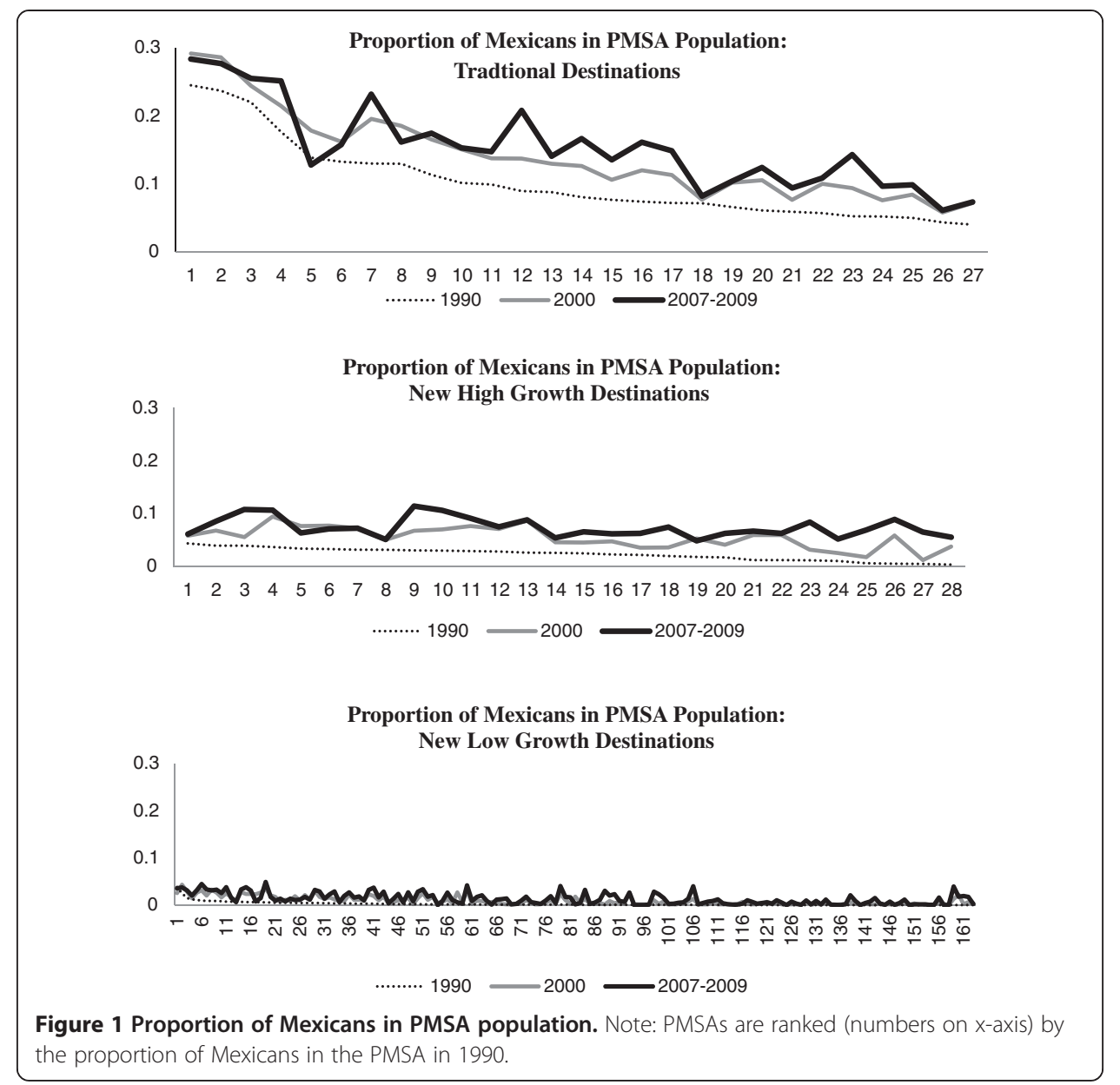

massive dispersion occurred such that in 2007-2009, only 46\% of the post-1990 arrivals lived in traditional destinations; $22 \%$ lived in new high-growth destinations, and $32 \%$ lived in new low-growth destinations. By 2000, 48 PMSAs had Mexican population density of over 4\%, and by 2007-2009 the number had climbed to 59. Figure 2 provides the geographic locations of the traditional, new high growth and new low-growth destinations. There are two points to note here: one, like traditional destinations, new high growth destinations are clustered in a few states. Two, most of the new high-growth destinations are either in close proximity to traditional PMSAs or other new high-growth destinations. The low-growth destinations, on the other hand, are more geographically dispersed across the country than the traditional and new high-growth destinations.

Our definition of traditional and new destinations is statistical and arguably, arbitrary for PMSAs that are close to the Mexican density cutoff of $4 \%$. We conducted the analysis excluding the new high and low growth PMSAs within 0.5 percentage points of the $4 \%$ density cutoff. There are two PMSAs in new high-growth destinations with a Mexican density of $4 \%$ to $4.5 \%$ in 2000. There are three PMSAs in new low-growth destinations within the $3.5 \%$ to $4 \%$ range. These five PMSAs constitute about four percent of our Mexican sample at the new destinations and less than two percent of the overall 


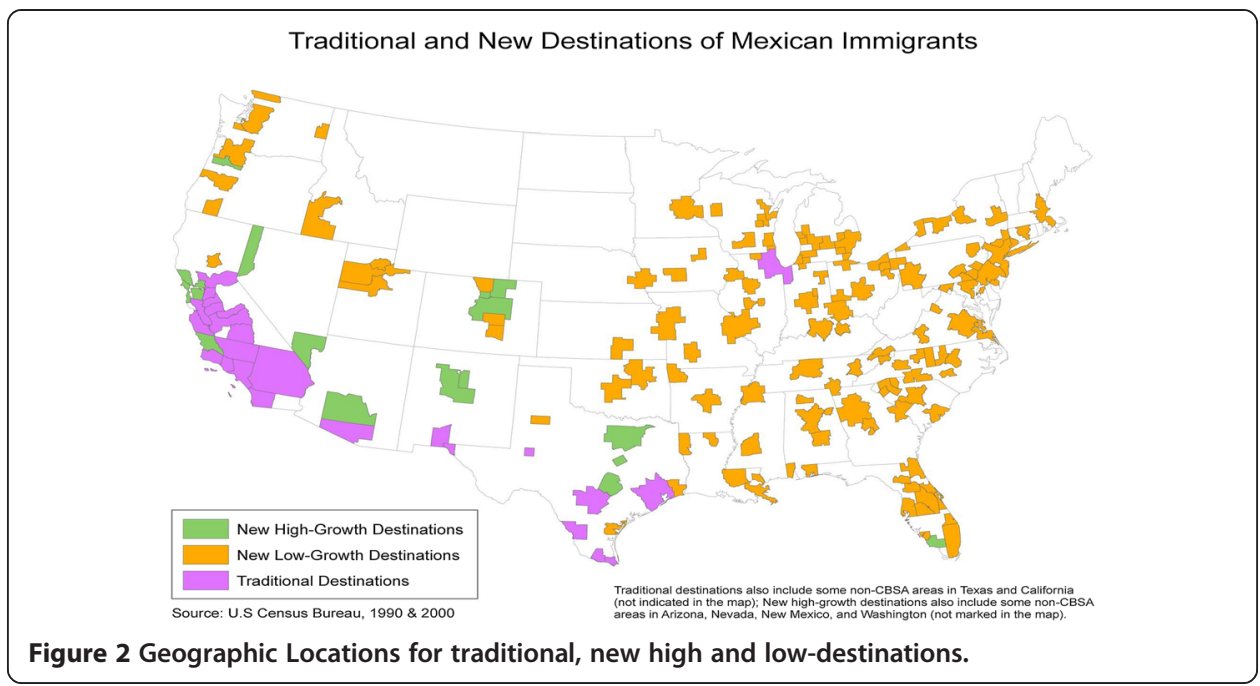

Mexican sample. Excluding these PMSAs did not alter the outcomes of the analysis. We also experimented with a $5 \%$ Mexican density cutoff and the results were similar ${ }^{6}$.

The Current Population Surveys, the data we use, do not allow us to determine whether migration is for family reunion or driven by economic opportunities. Because newer destinations have fewer Mexicans it is less likely that migration to these destinations if for family reunion. We estimated the difference in years since migration between the earliest arriving household member and the newly arrived Mexican immigrants (in the US for less than 5 years) at the three destinations: the average difference was eight years for new immigrants at the traditional destinations, six years for new Mexican immigrants at the new high-growth destinations, and four years for Mexican migrants at the new low-growth destinations. Further, we find that $44 \%$ of Mexicans at new low-growth destinations live in households where there are no earlier arrivals; the corresponding proportions are 33\% for Mexicans at the traditional destinations and $36 \%$ for Mexicans at the new high-growth destinations. These data provide some credence to our hypothesis that family reunion is less important in Mexican migration to new destinations, in particular new low-growth destinations.

Was Mexican dispersion to newer destinations related to any network externalities emanating from earlier migration of non-Mexicans with similar backgrounds (e.g. Central American migrants or migrants from Latin America, excluding Mexico)? We use Census 1990 and 2000 to investigate this issue. In 1990, immigrants from Central America comprised of $0.2 \%$ of the population at new low-growth destinations, in 2000 , the proportion increased to $0.6 \%$. The corresponding density of migrants from Latin America, excluding Mexico, was $1.1 \%$ in 1990 and 2.1\% in 2000. The proportions were similarly modest at new high-growth destinations: in 1990, 1.1\% of the population in new high-growth destinations was from Central America, in 2000, it rose to 2.4\%; the corresponding numbers for migrants from the rest of Latin America were $1.9 \%$ in 1990 and 3.5\% in 2000. These numbers are modest and do not provide any compelling evidence that Mexican dispersion to newer destinations was to exploit network externalities resulting from earlier migration of Central American or other Latin American migrants - because there is little evidence of such migration. On the 
other hand, these data suggest that migrants from Central America and rest of Latin America exhibit similar dispersion patterns as Mexican migrants.

\section{Data}

The empirical analysis uses the Current Population Survey, Outgoing Rotation Group files (CPS-ORG) from 2001 to $2009^{7}$. Because few Mexican immigrants in the new destinations migrated before 1980, we focus on adults (aged 18 to 64) who arrived in the US in 1980 or later. The CPS provides Metropolitan Statistical Area and Primary Metropolitan Statistical Area codes of residence for the 1996 to April 2004 period and the Combined Statistical Area of residence as defined by the Office of Management and Budget from May 2004 onwards. The CPS also contains data on county of residence for about $60 \%$ of the observations for the entire study period. We use the county-level information as well as a crosswalk prepared by the Bureau of Labor Statistics to create PMSA codes for the May 2004 to December 2009 data that match with the codes for January 1996 to April 2004.

The CPS-ORG provides information on individual characteristics such as age, sex, educational attainment, country of birth, and labor-market outcomes, which include employment status, usual hours worked per week, usual weekly earnings, hourly wage for hourly paid workers, and industry of employment. These data are used to create the outcome and control variables. Consumer price index from the Bureau of Labor Statistics is applied to convert the wage data to constant dollars (base year 1982$1984=100$ ). Observations with real wages of less than $\$ 2$ or more than $\$ 250$ are dropped from the wage analysis. The CPS provides data on period of arrival at two to three years intervals for those who arrived in the US in 1980 or later, which is used to assign immigrants to years-since-immigration categories. PMSA unemployment rates computed from CPS-ORG are used as a control in some model specifications. Real wage of second generation Mexicans (with at least one parent born in Mexico), by age (18-39 and 40-64), education (less than high-school, high-school, some college, and a bachelor's degree or more), destination (traditional, new high-growth, and new low-growth), gender, and year of the survey, constructed from the CPS-ORG, are used as control in some models.

The CPS interviews persons living within the same housing unit for four consecutive months, drops them from the survey for the next eight months, and re-enters them into the survey for the following four months. The CPS public-use data provide identifiers that can be used to match individuals in two consecutive years. Because the CPS sampling frame is residences and not people, we use a number of additional variables such as respondent's age, sex, race/ethnicity, nativity, state of residence, and period of arrival in the US to match individuals in years $\mathrm{t}-1$ and $\mathrm{t}$.

The CPS has a few limitations that may affect the analyses. The data on year of arrival are based on the question, "In which year did the respondent move to the US permanently?" The question is likely to be subject to different interpretations by repeat migrants; some may provide the year of first entry to the US and others may provide the year of the most recent entry (Redstone and Massey 2004). We assume that their responses refer to the year of permanent entry as specified in the question ${ }^{8}$. In the longitudinal sample, used in our preferred analysis, response to the above question is consistent for all respondents in years $t-1$ and $t$, suggesting low measurement error on 
this account. The second data issue relates to the length of the longitudinal panel. Theoretically, we cannot observe a difference in earnings over longer periods (e.g. ten years), without observing changes in earnings between short periods (e.g. two years). Thus, the issue is not whether observing a person one additional year is a sufficiently long time, which it is, but rather whether there is sufficient statistical power to detect potentially small changes.

\section{Empirical strategy: selection and earnings growth}

We first study the selection patterns of Mexican immigrants in the traditional, new high-growth and low-growth destinations. For this, we study the descriptive data on the demographic and labor-market characteristics of Mexico-born persons who have been in the US for five or fewer years. Next, we study earnings trajectories of Mexican immigrants at the three destinations using the following model on a sample of Mexicans, who arrived in the US in 1980 or later:

$$
\begin{aligned}
& \begin{aligned}
\operatorname{Ln}(\text { Wage })_{i j t}= & X_{i t} \beta+Z_{p t} \gamma+\sum_{m=1}^{M} \alpha_{m} * Y S I_{i m}+\sum_{m=1}^{M} \alpha_{m h} *\left(Y S I_{i m} * N H\right) \\
& +\sum_{m=1}^{M} \alpha_{m l} *\left(Y S I_{i m} * N L\right)+\eta_{t}+\lambda_{k}+\sigma_{j-(t-k)}+u_{i j k t}
\end{aligned} \\
& \mathrm{k}=1980-1989,1990-2000,2001-2009 \quad \text { (period of arrival) } \\
& \mathrm{t}=2001, \ldots ., 2009 \quad \text { (year of survey) } \\
& \mathrm{YSI}_{\mathrm{m}}=0-3,3-7,7-11,11-15,15-20,20-29 \text { years (years since immigration) }
\end{aligned}
$$

Ln (Wage) ${ }_{i j t}$, the log real wage of individual (i) of age (j) in year (t) is a function of the individual's characteristics $(X)$, namely age (a dummy variable for each year of age), education (< high school, high school, some college, and a bachelor's degree or higher), whether married, whether US citizen, industry of work, and location specific variables (Z), namely, PMSA unemployment rate, the real wage of second generation Mexicans ${ }^{9}$ (by age, education, destination, gender, and year of observation) and PMSA fixed effects. The variable $\lambda_{k}$ denotes period of arrival, $\eta_{t}$ denotes year of observation, $Y S I_{m}$ is years-since-immigration categories, and $\sigma_{j-(t-k)}$ is age at arrival. $N H$ is coded 1 if the respondent lives in a high-growth new destination and 0 otherwise; $N L$ is coded 1 if the respondent lives in low-growth new destination, and 0 otherwise. Age at arrival is measured as: $<15,15$ to 22,23 to 30,31 to 40 , and $>40$ years.

We address the collinearity between year of observation, year of arrival, and years since immigration (years since immigration = year of observation - year of arrival) by grouping observations by years since immigration and year of arrival. There is also perfect collinearity between age, age at arrival, and years since immigration [age at arrival $=$ age $-($ year of observation - year of arrival) $]$. Here too, we group the variable age at arrival into categories described above (see Mason et al. 1973 for a detailed discussion on cohort analysis). In Equation (1), the effects of age at arrival, period of arrival, and year of observation are restricted to be the same for immigrants living in the three destinations. Statistical tests rejected the restriction that year of observation has the same effect across destinations, but failed to reject the restriction that age at 
arrival and period of arrival has the same effect across destinations ${ }^{10}$. Therefore, in the empirical analysis we allow the effect of year of observation to differ across destinations, but restrict the effect of age at arrival and period of arrival to be the same. Note that inclusion of different year effects across destinations allow the effect of the great recession on Mexican immigrants to differ across destinations.

The parameter $\alpha_{m}$ estimates changes in wage earnings with time in the US at traditional destinations with newly arrived Mexican immigrants (in the US for 0-3 years) as the comparison category, and $\alpha_{m+} \alpha_{m h}$ and $\alpha_{m+} \alpha_{m l}$ estimate the same for Mexicans at the new high-growth and low-growth destinations. Throughout the analysis standard errors are computed by clustering on PMSA of residence using the Huber-White sandwich estimator.

Because there are fewer co-ethnic groups for social support, Mexicans at the newer destinations are more likely to be temporary migrants and more likely to return if they do poorly in the labor market compared with Mexicans at traditional destinations. A cross-sectional comparison of the earnings trajectories across destinations, as specified in Equation (1), is therefore likely to be affected by selective return migration. We address this issue by using longitudinal data that follow the same individuals over time. Equation (2) describes the longitudinal analysis carried out on a sample of Mexican immigrants:

$$
\begin{aligned}
\operatorname{Ln}(\text { Wage })_{i j t}= & \pi_{i}+X_{i t} \tilde{\beta}+Z_{p t} \tilde{\gamma}+\tilde{\delta}_{j}+\tilde{\eta}_{t} \\
& +\sum_{m=1}^{M} \tilde{\alpha} 2_{m t}\left(Y S I_{i(t-1) m} * Y E A R_{-} T * T r a d\right) \\
& +\sum_{m=1}^{M} \tilde{\alpha} 2_{m h}\left(Y S I_{i(t-1) m h} * Y E A R_{-} T * N H\right) \\
& +\sum_{m=1}^{M} \tilde{\alpha} 2_{m l}\left(Y S I_{i(t-1) m} * Y E A R_{-} T * N L\right)+u_{i j k t}
\end{aligned}
$$

There are three things to note about Equation (2). First, the equation includes person-specific fixed effects $\left(\pi_{i}\right)$. Second, each person is in the sample for two periods: $t-1$ and $t$, and the value of years since immigration in the US (YSI) is fixed at year $t-1$. Third, we allow the effect of YSI to differ by whether the observation is from year t-1 or t. In Equation (2) this choice is reflected by the interaction term (YSI $i(t-1) m$ * YEAR_T $)$. The parameters of interest are: $\tilde{\alpha} 2_{m t}, \tilde{\alpha} 2_{m h}$ and $\tilde{\alpha} 2_{m l}$, which measure changes in earnings of Mexican immigrants, between $\mathrm{t}-1$ and $\mathrm{t}$, at the traditional, new high-growth and low-growth destinations, respectively. Note that the main effect of years-sinceimmigration drops out of the model because in the longitudinal analysis this variable is time invariant for a specific immigrant.

Inclusion of person fixed effect reduces bias from selective return migration. In addition, our model allows controlling for unobserved location specific factors correlated with earnings in a parsimonious manner. This approach yields estimates of how the earnings of Mexican immigrants change with time in the US for the sample of immigrants who are present (i.e., have not exited the sample) for all the years-sinceimmigration categories at the three destinations. However, it is likely that certain types of individuals (e.g., those with more ambition) are selected to newer destinations (or traditional), and would therefore have faster earnings growth. Thus, arguably individual 
fixed effects do not eliminate the influence of individual-level factors altogether, particularly the factors that influence earnings growth rather than levels.

\section{Results: selection and earnings growth}

\section{Selection: new versus traditional destinations}

We first study if there are any distinct selection patterns among recently arrived Mexican immigrants at the three destinations. Descriptive data in Table 2 show generally low levels of educational attainment among Mexican men and women at the three destinations. Recently arrived, Mexican men at the new destinations are two percentage points more likely to be employed and have a 4-5\% higher real wage than Mexican men at the traditional destinations. Recently arrived, Mexican women at the new low growth destinations are 6 percentage points more likely to be employed than those at the traditional or new high growth destinations but there is no statistical difference in wages across destinations. These differences in labor market outcomes mostly disappear after adjusting for age, education, marital status, industry of work and citizenship status.

The industry level profiles of recent Mexican immigrants differ across destinations. During 2001-2009, the period covered by this study, 40\% of recently arrived Mexican men at the new high-growth destinations worked in construction versus only $26 \%$ of those at the traditional destinations and $34 \%$ in the low-growth destinations. Similarly, $37 \%$ of recently arrived Mexican women at the new high-growth destinations worked in retail/wholesale compared to only $30 \%$ at the traditional destinations and $31 \%$ at the low-growth destinations.

The last two rows of Table 2 provide data on residential moves since last year. These data are taken from the March CPS because the CPS-ORG does not include information on place of residence in the previous year. Ideally, we should compute internal migration with $\mathrm{t}-1$ as the base period. But the March CPS does not provide PMSA/MSA of residence in year $\mathrm{t}-1$. Thus, while we can compute internal migration with $\mathrm{t}-1$ as the base year, we cannot stratify our data in $\mathrm{t}-1$ by type of destination (traditional versus new high growth versus new low-growth). Therefore, we provide this data with current destination (period $t$ ) as reference.

Recent Mexican immigrants, in general, have a high propensity to change residences, and this propensity is higher among those living in the new destinations (high and low-growth) than among those in the traditional destinations. The difference continues to be statistically significant even after adjusting for age, education, marital status, industry of work and citizenship status. The vast majority of the moves, however, are within the same state. About $1 \%$ of Mexicans in the traditional destinations and 4 to $6 \%$ of Mexicans in the new destinations lived in a different state in the preceding year ${ }^{11}$. This provides some partial evidence that the migration between the three types of destinations in our sample is likely to be modest.

To sum up, the descriptive data suggest that the geographic dispersion of recent Mexican immigrant men has been associated with both immigrant characteristics (selection) and labor market opportunities at the newer destinations. Further, the influx of Mexican men to new destinations could partly be driven by the construction boom of the past decade as indicated by 34 to $40 \%$ of all recently arrived Mexican men at the new destinations working in construction. It is also likely that to some extent the boom was facilitated by the influx of low-skilled labor. 
Table 2 Descriptive statistics: mexican men and women aged 18-64, CPS outgoing rotation 2001-2009

\begin{tabular}{|c|c|c|c|c|c|c|c|c|c|c|c|c|}
\hline & \multicolumn{6}{|l|}{ Men } & \multicolumn{6}{|c|}{ Women } \\
\hline & \multicolumn{3}{|c|}{ Mexico-born } & \multicolumn{3}{|c|}{ Newly arrived Mexico-born } & \multicolumn{3}{|c|}{ Mexico-born } & \multicolumn{3}{|c|}{ Newly arrived Mexico-born } \\
\hline & Trad & $\begin{array}{l}\text { New high } \\
\text { growth }\end{array}$ & $\begin{array}{l}\text { New low } \\
\text { growth }\end{array}$ & Trad & $\begin{array}{l}\text { New high } \\
\text { growth }\end{array}$ & $\begin{array}{l}\text { New low } \\
\text { growth }\end{array}$ & Trad & $\begin{array}{l}\text { New high } \\
\text { growth }\end{array}$ & $\begin{array}{l}\text { New low } \\
\text { growth }\end{array}$ & Trad & $\begin{array}{l}\text { New high } \\
\text { growth }\end{array}$ & $\begin{array}{l}\text { New low } \\
\text { growth }\end{array}$ \\
\hline Age & 34.66 & $33.24 \sim$ & $32.01 \sim+$ & 29.53 & $28.98 \sim$ & $28.69 \sim$ & 35.54 & $33.96 \sim$ & $32.71 \sim+$ & 31.56 & $30.59 \sim$ & $29.36 \sim+$ \\
\hline \multicolumn{13}{|l|}{ Education: } \\
\hline$\%$ less than high school & 61.20 & 62.90 & $60.45+$ & 66.82 & 66.32 & $62.46 \sim+$ & 60.22 & 60.50 & 59.79 & 61.17 & 61.34 & 59.84 \\
\hline$\%$ high school & 24.72 & 25.32 & $28.92 \sim+$ & 21.42 & $24.98 \sim$ & $27.96 \sim+$ & 23.81 & $25.82 \sim$ & $26.55 \sim$ & 22.01 & $25.23 \sim$ & $26.82 \sim$ \\
\hline$\%$ some college & 9.77 & $7.53 \sim$ & $6.53 \sim+$ & 7.13 & 4.87 & $5.54 \sim$ & 10.98 & $9.16 \sim$ & $7.95 \sim+$ & 10.39 & $7.50 \sim$ & $6.56 \sim$ \\
\hline$\%$ college or higher & 4.32 & 4.25 & 4.11 & 4.63 & 3.83 & 4.04 & 4.99 & 4.53 & $5.71 \sim+$ & 6.42 & 5.93 & 6.78 \\
\hline$\%$ married & 65.28 & $62.03 \sim$ & $56.54 \sim+$ & 47.59 & 46.12 & $42.51 \sim+$ & 68.06 & 69.13 & 67.90 & 63.88 & 66.51 & 64.10 \\
\hline \multicolumn{13}{|l|}{ Labor Market Outcomes } \\
\hline$\%$ currently employed & 86.30 & $88.97 \sim$ & 89.29 & 86.99 & 88.59 & $89.15 \sim$ & 45.54 & 45.94 & $48.52 \sim+$ & 37.60 & 37.56 & $43.80 \sim+$ \\
\hline Avg. hours worked per week & 38.14 & 38.41 & $38.85 \sim+$ & 38.11 & 37.75 & $38.58+$ & 32.48 & $33.14 \sim$ & $33.77 \sim+$ & 31.29 & 32.05 & $33.78 \sim+$ \\
\hline Real wage & 6.07 & 6.16 & $5.82 \sim+$ & 5.16 & $5.36 \sim$ & $5.34 \sim$ & 5.10 & 5.08 & $4.89 \sim+$ & 4.70 & 4.55 & 4.52 \\
\hline Log real wage & 1.69 & $1.72 \sim$ & $1.67 \sim+$ & 1.55 & $1.60 \sim$ & $1.59 \sim$ & 1.53 & 1.53 & $1.51+$ & 1.46 & 1.44 & 1.45 \\
\hline \multicolumn{13}{|l|}{ Adjusted outcomes ${ }^{1}$} \\
\hline$\%$ currently employed & 82.61 & $85.11 \sim$ & $84.31 \sim$ & 82.07 & 84.06 & 83.84 & 54.5 & $58.6 \sim$ & $56.93 \sim$ & 52.15 & 54.22 & $56.16 \sim$ \\
\hline Avg. hours worked per week & 37.69 & $38.67 \sim$ & $39.18 \sim$ & 37.39 & 37.87 & 38.79 & 31.44 & $32.73 \sim$ & $32.83 \sim$ & 30.95 & 32.15 & $33.23 \sim$ \\
\hline Real wage & 5.88 & 5.98 & 5.77 & 5.40 & 5.60 & 5.61 & 5.15 & 5.19 & 5.07 & 4.84 & 4.93 & 4.82 \\
\hline Log real wage & 1.65 & 1.69 & 1.65 & 1.57 & 1.62 & $1.62 \sim$ & 1.52 & 1.53 & 1.52 & 1.48 & 1.51 & 1.49 \\
\hline \multicolumn{13}{|l|}{ Industry of employment } \\
\hline$\%$ working in agriculture & 7.42 & $5.02 \sim$ & $8.13 \sim+$ & 11.15 & $5.24 \sim$ & $8.91 \sim+$ & 3.99 & $2.20 \sim$ & $3.14 \sim+$ & 6.63 & $1.24 \sim$ & $3.66 \sim+$ \\
\hline$\%$ working in manufacturing & 17.73 & $9.42 \sim$ & $18.09+$ & 15.71 & $8.75 \sim$ & $14.42+$ & 18.27 & $9.62 \sim$ & $24.75 \sim+$ & 17.87 & $10.68 \sim$ & $22.05 \sim+$ \\
\hline$\%$ working in construction & 23.15 & $36.23 \sim$ & $31.27 \sim+$ & 26.10 & $39.80 \sim$ & $33.66 \sim+$ & 1.15 & 1.53 & 1.47 & 1.46 & 2.32 & 2.08 \\
\hline
\end{tabular}


Table 2 Descriptive statistics: mexican men and women aged 18-64, CPS outgoing rotation 2001-2009 (Continued)

\begin{tabular}{|c|c|c|c|c|c|c|c|c|c|c|c|c|}
\hline $\begin{array}{l}\% \text { working in retail/trade/ } \\
\text { whole sale }\end{array}$ & 21.46 & $19.81 \sim$ & $20.09 \sim$ & 23.01 & 22.49 & 21.25 & 26.51 & $29.99 \sim$ & $26.46+$ & 29.89 & $36.53 \sim$ & $30.53+$ \\
\hline$\%$ working in other industries & 30.24 & 29.53 & $22.41 \sim+$ & 24.04 & 23.72 & $21.76 \sim$ & 50.08 & $56.66 \sim$ & $44.18 \sim+$ & 44.16 & 49.23 & $41.68+$ \\
\hline \multicolumn{13}{|l|}{ Internal Migration ${ }^{1}$} \\
\hline$\%$ moved & 17.99 & $22.36 \sim$ & $24.38 \sim+$ & 27.07 & $35.28 \sim$ & $34.71 \sim$ & 15.41 & $20.27 \sim$ & $21.45 \sim$ & 25.14 & $30.91 \sim$ & $33.26 \sim$ \\
\hline$\%$ Inter-state Migration & 0.82 & 2.92 & $3.79 \sim+$ & 1.10 & $5.18 \sim$ & $5.69 \sim$ & 0.91 & 2.99 & $3.77 \sim$ & 1.09 & 3.64 & $5.08 \sim$ \\
\hline Adjusted\% moved ${ }^{1}$ & 17.43 & 20.38 & 21.38 & 23.86 & 31.29 & 30.21 & 16.64 & 20.63 & $21.09 \sim$ & 23.54 & 28.16 & 29.22 \\
\hline $\begin{array}{l}\text { Adjusted\% Inter-state } \\
\text { Migration' }\end{array}$ & 1.00 & $3.00 \sim$ & $3.71 \sim$ & 1.96 & 5.97 & $6.53 \sim$ & 1.27 & $3.25 \sim$ & $4.02 \sim$ & 1.30 & $3.91 \sim$ & $5.40 \sim$ \\
\hline $\mathrm{N}$ & 15779 & 8964 & 14113 & 2568 & 2218 & 4582 & 15289 & 7534 & 9644 & 2367 & 1720 & 2744 \\
\hline
\end{tabular}

Note: Traditional destinations (Trad) are defined as PMSAs with at least 4\% of the population born in Mexico in 1990; new high growth destinations are non-traditional PMSAs with at least 4\% population born in

Mexico in 2000; new low-growth destinations are non-traditional PMSAs with less than 4\% of the population born in Mexico in 2000. Newly arrived are immigrants in the US for 5 or fewer years. Samples are restricted to Mexicans who arrived in the US in 1980 or later. ${ }^{1}$ Adjusted for age, education, industry of work, marital status, citizenship status of the foreign-born. + indicates that the means for new high-growth and low-growth destinations are significantly different at a $95 \%$ confidence interval. indicates that the means for traditional and new destinations (high or low-growth) are significantly different at a $95 \%$ confidence interval. ${ }^{2}$ Based on March CPS data. 


\section{Earnings trajectories: cross-sectional}

Table 3 presents estimated coefficients based on Equation (1). New arrivals (in the US for 0-3 years) are the comparison category. Results in Columns 1 and 4 suggest a modest growth in Mexican immigrants' wages with time in the US: two to three decades of residency in the US is associated with a $10 \%$ increase in the hourly wage of men and an $8 \%$ increase in the hourly wage of Mexican women. This finding is similar to previous research that used data for 2000 or earlier (see, for example, Borjas and Katz 2007). More recent arrival cohorts have a lower wage than earlier arrivals (not shown in Table 3). Further, Mexicans who arrived in the US at a younger age have a wage advantage over those who arrived at an older age, but in women's regressions the coefficients on the age at arrival variables are often statistically insignificant (not shown in Table 3).

Mexican men in the US for 3-15 years who live in high-growth new destinations earn a 3 to 5 percent higher wage than comparable Mexican men at the traditional destinations; there is no statistically significant difference in the real wage of Mexican men at the traditional and new high-growth destinations in other YSI categories (column 2). Mexican men at the new low growth destinations who have been in the US for more than 15 years have a lower wage than similar Mexican men at the traditional destinations. Further, statistical tests suggest that the real wage of Mexican men at the new high-growth destinations is higher than that of Mexican men at the new low-growth destinations. In the women's analysis too, there is evidence that the real wage in the new high growth destinations is higher than the real wage in the traditional destinations, and there is no clear indication of the wage gap disappearing with time in the US.

Regressions in Table 3 allow year effect to differ across destinations. Our estimates (not presented in the Table) show that in 2009 the adjusted wage of Mexican men was statistically lower in the newer destinations than in the traditional ones, and in the women's analysis, during 2006-2009, the adjusted wage was statistically lower in new high-growth destinations than in the traditional ones, suggesting that during the Great Recession Mexican workers were more adversely affected in the newer than the traditional destinations. A serious limitation of the analysis examining multiple years of cross-sectional data is that the estimates are likely to be biased if return migration is selective on earnings, an issue we investigate in detail below. First, however, we use the two-year panel (matched data) of the CPS to study changes in real wages with an additional year of stay in the US.

\section{Earnings analysis: longitudinal data}

Table 4 presents changes in the log real wages of Mexican immigrants between years t-1 and t. During 2001-2009, the real wages increased 1.9\% annually for Mexican men living in the traditional destinations, $0.4 \%$ for Mexican men living in the new highgrowth destinations, and $1.9 \%$ for those in the new low-growth destinations. Statistical tests fail to reject the hypothesis that wage growth was the same across the traditional and new low growth destinations; but reject the hypothesis of equality in wage growth across the new high-growth and traditional destinations. Over the same period, the real wage increased $1.3 \%$ annually for Mexican women in the traditional destinations, $0.9 \%$ for Mexican women in the new high growth destinations and 2.2\% for Mexican women 
Table 3 Estimates of the association between log real wage and years since arrival in the US of Mexican Immigrants, CPS outgoing rotation 2001-2009, cross-sectional data

\begin{tabular}{|c|c|c|c|c|c|c|}
\hline & \multicolumn{3}{|c|}{ Mexican men } & \multicolumn{3}{|c|}{ Mexican women } \\
\hline & 1 & 2 & 3 & 4 & 5 & 6 \\
\hline \multicolumn{7}{|l|}{ Years since immigration } \\
\hline \multirow[t]{2}{*}{ YSI =3-7 years } & 0.013 & 0.003 & -0.0002 & 0.005 & 0.002 & 0.003 \\
\hline & $(0.009)$ & $(0.011)$ & $(0.011)$ & $(0.013)$ & $(0.024)$ & $(0.025)$ \\
\hline \multirow[t]{2}{*}{ YSI =7-11 years } & $0.023^{* *}$ & $0.028^{* *}$ & 0.017 & 0.003 & -0.022 & -0.025 \\
\hline & $(0.011)$ & $(0.013)$ & $(0.013)$ & $(0.022)$ & $(0.022)$ & $(0.023)$ \\
\hline \multirow[t]{2}{*}{$\mathrm{YSI}=11-15$ years } & $0.054^{* * *}$ & $0.051^{* * *}$ & $0.049^{* * *}$ & 0.016 & -0.003 & -0.007 \\
\hline & $(0.015)$ & $(0.016)$ & $(0.015)$ & $(0.026)$ & $(0.026)$ & $(0.026)$ \\
\hline \multirow[t]{2}{*}{$Y S I=15-20$ years } & $0.075^{* * *}$ & $0.085^{* * *}$ & $0.064^{* * *}$ & $0.051^{*}$ & 0.036 & 0.021 \\
\hline & $(0.020)$ & $(0.020)$ & $(0.019)$ & $(0.029)$ & $(0.031)$ & $(0.030)$ \\
\hline \multirow[t]{2}{*}{$\mathrm{YSI}=20-29$ years } & $0.095^{* * *}$ & $0.124^{* * *}$ & $0.097^{* *}$ & $0.083^{* *}$ & $0.070^{* *}$ & 0.036 \\
\hline & $(0.024)$ & $(0.023)$ & $(0.023)$ & $(0.036)$ & $(0.032)$ & $(0.032)$ \\
\hline \multirow[t]{2}{*}{ 3-7 years*New high-growth } & - & $0.049^{* * *}$ & $0.052^{* * *}$ & - & 0.023 & 0.027 \\
\hline & & $(0.014)$ & $(0.015)$ & & $(0.030)$ & $(0.029)$ \\
\hline \multirow[t]{2}{*}{$7-11$ years *New high-growth } & - & $0.034^{*}$ & $0.042^{* *}$ & - & $0.084^{* *}$ & $0.093^{* * *}$ \\
\hline & & $(0.020)$ & $(0.019)$ & & $(0.034)$ & $(0.032)$ \\
\hline \multirow[t]{2}{*}{ 11-15 years *New high-growth } & - & $0.043^{* *}$ & $0.045^{* *}$ & - & $0.059^{*}$ & $0.066^{* *}$ \\
\hline & & $(0.021)$ & $(0.020)$ & & $(0.031)$ & $(0.031)$ \\
\hline \multirow[t]{2}{*}{$15-20$ years *New high-growth } & - & 0.021 & 0.030 & - & 0.048 & $0.059^{*}$ \\
\hline & & $(0.029)$ & $(0.026)$ & & $(0.031)$ & $(0.032)$ \\
\hline \multirow[t]{2}{*}{ 20-29 years*New high-growth } & - & -0.010 & -0.0003 & - & $0.045^{*}$ & $0.059^{* *}$ \\
\hline & & $(0.026)$ & $(0.022)$ & & $(0.025)$ & $(0.025)$ \\
\hline \multirow[t]{2}{*}{ 3-7 years* New low-growth } & - & $-0.002+$ & $-0.005+$ & - & -0.003 & -0.001 \\
\hline & & $(0.015)$ & $(0.015)$ & & $(0.030)$ & $(0.030)$ \\
\hline \multirow[t]{2}{*}{ 7-11 years* New low-growth } & - & $-0.027+$ & $-0.025+$ & - & $0.023+$ & $0.028+$ \\
\hline & & $(0.017)$ & $(0.016)$ & & $(0.028)$ & $(0.029)$ \\
\hline \multirow[t]{2}{*}{$11-15$ years * New low-growth } & - & $-0.015+$ & $-0.021+$ & - & 0.023 & 0.026 \\
\hline & & $(0.019)$ & $(0.016)$ & & $(0.031)$ & $(0.032)$ \\
\hline \multirow[t]{2}{*}{$15-20$ years * New low-growth } & - & $-0.038^{*}+$ & $-0.027+$ & - & 0.019 & 0.026 \\
\hline & & $(0.020)$ & $(0.019)$ & & $(0.033)$ & $(0.034)$ \\
\hline \multirow[t]{2}{*}{ 20-29 years* New low-growth } & - & $-0.086^{* * *}+$ & $-0.069^{* * *}+$ & - & 0.015 & 0.028 \\
\hline & & $(0.023)$ & $(0.020)$ & & $(0.031)$ & $(0.031)$ \\
\hline $\mathrm{N}$ & 30908 & 30908 & 30908 & 13656 & 13656 & 13656 \\
\hline
\end{tabular}

Note: Figures in each column are based on a single regression. Samples are restricted to Mexican men (columns 1-3) and Mexican women (columns 4-6) who arrived in the US in 1980 or later. See notes to Table 2 for the definitions of destinations. All regressions control for age (a dummy variable for each year of age), period of arrival and age at arrival, PMSA unemployment rate, average real wage of second generation Mexicans (by age, education, destination, gender, and year of observation), PMSA and year of observation effects. The effects of year of observations in columns $2,3,5$ and 6 are allowed to differ across destinations because statistical tests reject the restricted models. Models 3 and 6 also include controls for educational attainment, marital status, citizenship status and industry of work. Standard errors clustered around PMSA of residence are in parentheses. + indicates the coefficients for new high-growth and low-growth destinations are significantly different at $95 \%$ confidence interval. ${ }^{*} 0.05<\mathrm{p} \leq 0.1,{ }^{* *} 0.01<\mathrm{p} \leq 0.05,{ }^{* * *} \mathrm{p} \leq 0.01$.

in the new low-growth destinations. Statistical tests fail to reject the hypothesis that women's wage growth is statistically the same across the three destinations.

Comparing the point estimates of wage growth of Mexican immigrants with those of second generation low-educated Mexicans (bottom row), we find that whereas the 
Table 4 Estimates of change in log real wage, between $t-1$ and $t$, of Mexico-born men and women, by years since arrival in the US, CPS outgoing rotation 2001-2009, matched data

\begin{tabular}{|c|c|c|c|c|c|c|}
\hline \multirow{2}{*}{$\begin{array}{l}\text { Years since } \\
\text { immigration (YSI) }\end{array}$} & \multicolumn{3}{|l|}{ Men } & \multicolumn{3}{|l|}{ Women } \\
\hline & Traditional & $\begin{array}{l}\text { New high } \\
\text { growth }\end{array}$ & $\begin{array}{l}\text { New low } \\
\text { growth }\end{array}$ & Traditional & $\begin{array}{l}\text { New high } \\
\text { growth }\end{array}$ & $\begin{array}{l}\text { New low } \\
\text { growth }\end{array}$ \\
\hline \multirow[t]{2}{*}{$Y S I=0-3$} & -0.002 & -0.017 & 0.014 & 0.003 & -0.005 & 0.017 \\
\hline & $(0.022)$ & $(0.033)$ & $(0.031)$ & $(0.052)$ & $(0.044)$ & $(0.036)$ \\
\hline \multirow[t]{2}{*}{$Y S I=3-7$} & 0.033 & $0.059^{* * *}$ & $0.041^{*}$ & 0.003 & -0.025 & 0.041 \\
\hline & $(0.022)$ & $(0.021)$ & $(0.021)$ & $(0.023)$ & $(0.026)$ & $(0.033)$ \\
\hline \multirow[t]{2}{*}{$Y S I=7-11$} & 0.015 & 0.021 & 0.012 & 0.012 & $0.077^{*}$ & -0.018 \\
\hline & $(0.012)$ & $(0.025)$ & $(0.019)$ & $(0.019)$ & $(0.039)$ & $(0.029)$ \\
\hline \multirow[t]{2}{*}{$Y S I=11-15$} & -0.003 & $-0.036^{*}$ & $0.041^{*}+$ & 0.017 & $0.044^{*}$ & -0.008 \\
\hline & $(0.014)$ & $(0.022)$ & $(0.022)$ & $(0.018)$ & $(0.026)$ & $(0.032)$ \\
\hline \multirow[t]{2}{*}{$Y S I=15-20$} & 0.013 & -0.006 & $0.049^{* *}$ & 0.015 & 0.004 & $0.076^{*}$ \\
\hline & $(0.012)$ & $(0.016)$ & $(0.024)$ & $(0.017)$ & $(0.027)$ & $(0.044)$ \\
\hline \multirow[t]{2}{*}{$Y S I=20-29$} & $0.024^{* *}$ & 0.029 & -0.016 & 0.005 & -0.001 & 0.014 \\
\hline & $(0.010)$ & $(0.021)$ & $(0.024)$ & $(0.020)$ & $(0.057)$ & $(0.035)$ \\
\hline \multirow[t]{2}{*}{ All Mexico-born } & $0.019^{* * *}$ & $0.004 \sim$ & $0.019^{* *}$ & $0.013^{*}$ & 0.009 & 0.022 \\
\hline & $(0.005)$ & $(0.006)$ & $(0.009)$ & $(0.007)$ & $(0.009)$ & $(0.013)$ \\
\hline \multirow{2}{*}{$\begin{array}{l}\text { Second-generation } \\
\text { Mexicans }\end{array}$} & $0.055^{* * *}$ & $0.057^{* *}$ & 0.032 & $0.038^{* * *}$ & $0.049^{* * *}$ & 0.029 \\
\hline & $(0.010)$ & $(0.023)$ & $(0.024)$ & $(0.008)$ & $(0.012)$ & $(0.021)$ \\
\hline $\begin{array}{l}\text { Second-generation } \\
\text { Mexicans with }\end{array}$ & $0.052^{* * *}$ & $0.047^{* *}$ & 0.033 & $0.037^{* * *}$ & 0.031 & -0.013 \\
\hline High-school or less & $(0.014)$ & $(0.023)$ & $(0.028)$ & $(0.009)$ & $(0.023)$ & $(0.029)$ \\
\hline
\end{tabular}

Note: See notes to Table 2 for the definitions of destinations. Mexico-born samples are restricted to individuals who arrived in the US in 1980 or later. Robust standard errors clustered on PMSA of residence are in parenthesis. + indicates that the coefficients for new high-growth and new low growth destinations are significantly different at a $95 \%$ confidence interval. indicates that the coefficients for traditional and new destinations (high or low-growth) are significantly different at a $95 \%$ confidence interval. ${ }^{*} 0.05<p \leq 0.1,{ }^{* *} 0.01<p \leq 0.05,{ }^{* * *} p \leq 0.01$.

first-generation Mexican men and women experienced a positive annual wage growth during 2001-2009, it was generally modest in comparison to the annual growth experienced by the second-generation Mexican men and women. Estimates of earnings growth by years since immigration are often positive and sometimes statistically significant, but there is no clear trend across destinations or across years since immigration categories.

Next, we investigate the effect of an additional year of residence in the US on the real wage of Mexico-born men and women, using person-fixed-effects models based on Equation (2) (Table 5). In this analysis we explicitly adjust for local economic conditions by including controls for the real wage of second generation Mexicans and the PMSA unemployment rate. These models also allow the year effects to differ across destinations.

Estimates suggest that the average real wage of Mexican men, after adjusting for a rich set of variables, changes by -1.8 to $1.2 \%$ with one additional year of US residency, and the estimates are always statistically insignificant. The increase in the real wages of Mexican women with an additional year in the US is 1 to $4 \%$, and is statistically significant for women who have been in the country for 11 to 20 years. There is no noticeable 
Table 5 Estimates of the association between log real wage and years since immigration in the US, CPS outgoing rotation 2001-2009, longitudinal analysis (Person-Fixed-Effects Model)

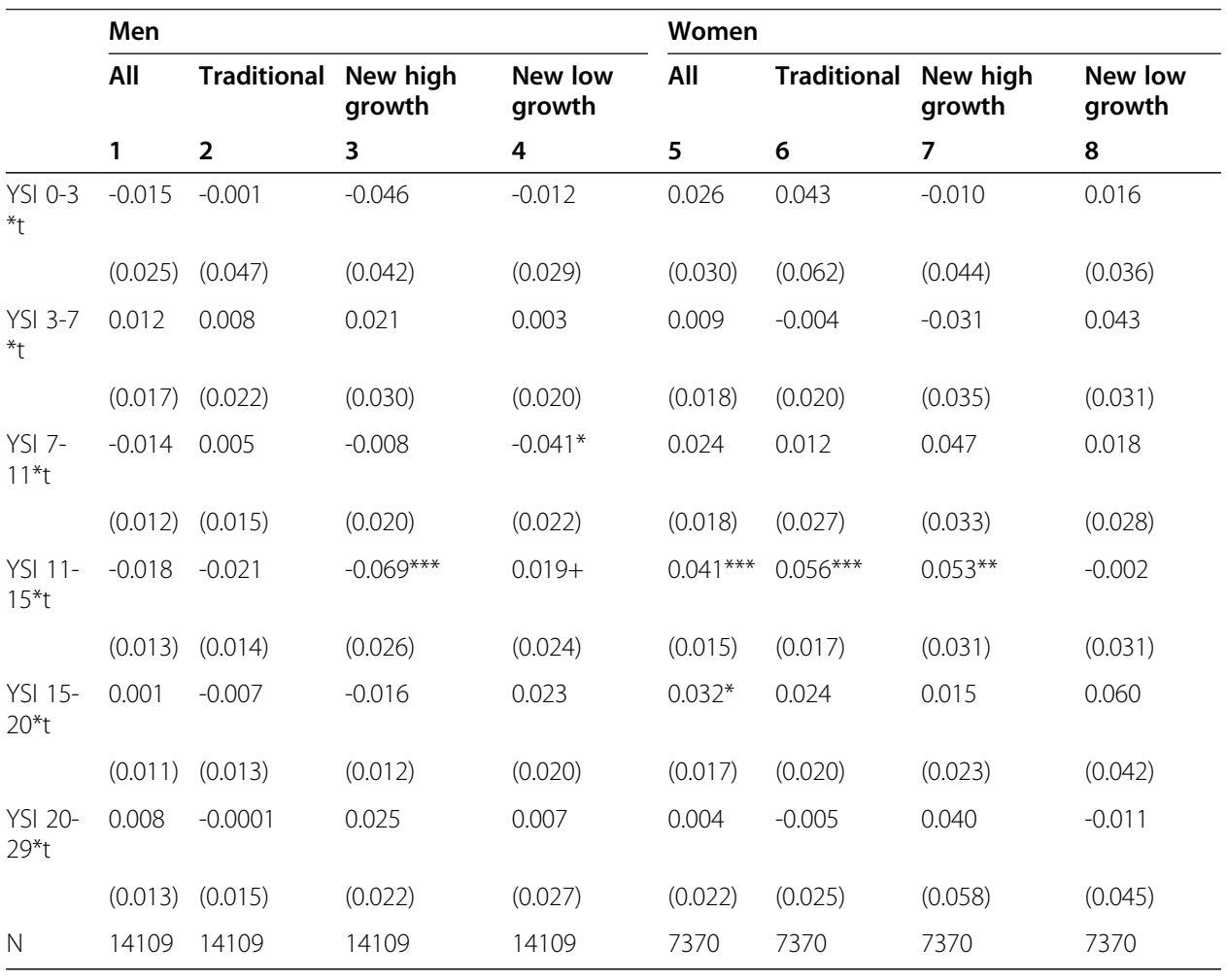

Note: See notes to Table 2 for the definitions of destinations. Figures in columns 1 and 5 are based on separate regressions with log real wage as the dependent variable. Years-since-immigration (YSI) is measured as of $\mathrm{t}-1$ and is the same for an individual in both periods t-1 and t. All regressions control for individual fixed effects, age (a dummy variable for each year of age), education, whether married, whether citizen, industry of work, average real wage of second generation Mexicans (by age, education, destination, year of observation and gender), year of observation, and PMSA unemployment rate. Figures in columns 2-4 and 6-8 are also based on separate regressions, where the effect of years-since-immigration is allowed to differ across destinations with the inclusion of three way interactions of: years since immigration, whether the respondent lives in a traditional (or new high-growth or new low growth) destination and whether the observation is taken from year t. Similarly we also allow the effect of year of observation to differ across destinations in the regressions in columns $2-4$ and 6-8. + indicates that the coefficients for new high-growth and new low growth destinations are significantly different at a $95 \%$ confidence interval. indicates that the coefficients for traditional and new destinations (high or low-growth) are significantly different at a $95 \%$ confidence interval. Standard errors clustered on PMSA of residence are in parenthesis. ${ }^{*} 0.05<\mathrm{p} \leq 0.1,{ }^{* *} 0.01<\mathrm{p} \leq 0.05,{ }^{* * *} \mathrm{p} \leq 0.01$.

trend in wage growth with time in the US (rising or falling). In models that compute the adjusted annual earnings by place of residence, statistical tests fail to reject the hypothesis that the wage growth is the same in the traditional and newer destinations.

\section{Return migration - empirical strategy}

Our primary objective in this paper is to study three migration processes - selection, assimilation and return migration - in a single and coherent framework. In the previous sections, we studied the selection and earnings growth of Mexican immigrants at the newer and traditional destinations. We now turn to investigating return migration and whether it is selective on immigrant earnings performance in the US. We begin by first investigating whether the propensity to return to Mexico differs for Mexican immigrants across the three destinations using a somewhat modified version of the methodology applied by Van Hook, Passel, Bean, \& Zhang $(2006)^{12}$. The methodology exploits the longitudinal feature of the CPS. In the CPS, an immigrant interviewed in year $\mathrm{t}-1$ cannot 
be followed up in the subsequent interview in year $t$ if he or she died in the intervening period (D), moved to another address within the US (IM), emigrated to another country (E), or was not tracked for other data-related reasons (NM). Equation (3) describes the non-follow-up (L) of Mexican immigrants who lived at the traditional destination in year $\mathrm{t}-1$ :

$$
L_{i t}=D_{i t}+I M_{i t}+E_{i t}+N M_{i t}
$$

Similar equations can be used to describe the non-follow-up of Mexican immigrants at the new high- and low-growth destinations.

We use the National Health Interview Surveys-National Death Index (NHIS-NDI) to compute the probability of death of first- and second-generation Mexicans by each year of age and sex. The CPS-ORG does not provide data on internal migration. We use the March CPS, which provides data on whether the respondent changed residences between $t-1$ and $t$, and impute this outcome for second-generation Mexicans in the CPS-ORG for year $\mathrm{t}-1$ using the following set of regression variables: age (a dummy variable for each year of age), education (< high school, high school, some college, and a bachelor's degree or higher), sex, whether married, whether employed, industry of work, year of observation, and state of residence in year $\mathrm{t}-1^{13}$. Four additional variables are added in imputing whether moved residence for first-generation Mexicans: whether US citizen, period of arrival, age at arrival, and years-since-immigration categories. Assuming that the probability of outmigration for the second generation is zero ${ }^{14}$, we arrive at the residual nonmatch rate (for other reasons) for second-generation Mexicans who live in the traditional destinations:

$$
N M_{s t}=L_{s t}-D_{s t}-I M_{s t}
$$

Further assuming that conditional on demographic characteristics, the probability of a residual nonmatch in the traditional destinations is the same for the first and second generation immigrants, we predict the outmigration rate of the first generation Mexicans in the traditional destinations (Equation 5) ${ }^{15}$.

$$
\hat{E}_{i t}=L_{i t}-\hat{D}_{i t}-I \hat{M}_{i t}-N \hat{M}_{i t}
$$

In the same manner, we predict the outmigration rate of first generation Mexicans living in the new high growth and low growth destinations.

To investigate if return migration is selective on past earnings, we regress wages in year $\mathrm{t}-1$ on the predicted probability of return migration of Mexican immigrants. We also study if the association between past earnings and return migration differs at the three destinations. Return migration would be negatively selected if the coefficient on predicted return migration is negative. Our hypothesis is that return migration among Mexican immigrants at newer destinations would be more negatively selected on past wages because Mexicans at the newer destinations do not have much family or network that would support them at these destinations in bad economic times.

\section{Return migration - results}

Table 6 provides a summary statement of predicted return migration of first-generation Mexicans and the variables used in its computation. Mexicans in the traditional destinations exhibited greater residential stability: internal migration, non-follow up in the 
Table 6 Summary of non-follow-up, predicted mortality, internal migration, residual nonmatch, and predicted outmigration, CPS outgoing rotation 2001-2009

\begin{tabular}{|c|c|c|c|c|c|c|c|c|c|c|}
\hline & \multicolumn{5}{|c|}{ Panel 1: Men } & \multicolumn{5}{|c|}{ Panel 2: Women } \\
\hline & $\begin{array}{l}\text { Non- } \\
\text { follow- } \\
\text { up }\end{array}$ & $\begin{array}{l}\text { Imputed } \\
\text { probability of } \\
\text { mortality }^{1}\end{array}$ & $\begin{array}{l}\text { Imputed probability of } \\
\text { internal migration }\end{array}$ & $\begin{array}{c}\text { Residual } \\
\text { nonmatch }^{3}\end{array}$ & $\begin{array}{l}\text { Predicted } \\
\text { out- } \\
\text { migration }\end{array}$ & $\begin{array}{l}\text { Non- } \\
\text { follow- } \\
\text { up }\end{array}$ & $\begin{array}{l}\text { Imputed } \\
\text { Probability of } \\
\text { mortality }^{1}\end{array}$ & $\begin{array}{l}\text { Imputed probability of } \\
\text { internal migration }\end{array}$ & $\begin{array}{c}\text { Residual } \\
\text { nonmatch }^{3}\end{array}$ & $\begin{array}{c}\text { Predicted } \\
\text { out- } \\
\text { migration }\end{array}$ \\
\hline & 1 & 2 & 3 & 4 & 5 & 6 & 7 & 8 & 9 & 10 \\
\hline \multicolumn{11}{|l|}{$\begin{array}{l}\text { Traditional } \\
\text { Destinations }\end{array}$} \\
\hline \multirow{2}{*}{$\begin{array}{l}\text { First } \\
\text { Generation }\end{array}$} & 0.397 & 0.004 & 0.189 & 0.151 & 0.053 & 0.330 & 0.004 & 0.166 & 0.145 & 0.015 \\
\hline & $(0.006)$ & $(0.00002)$ & $(0.001)$ & $(0.001)$ & $(0.005)$ & $(0.005)$ & $(0.00002)$ & $(0.001)$ & $(0.001)$ & $(0.005)$ \\
\hline \multirow{2}{*}{$\begin{array}{c}\text { Second } \\
\text { Generation }\end{array}$} & 0.311 & 0.003 & 0.170 & 0.137 & - & 0.291 & 0.002 & 0.147 & 0.142 & - \\
\hline & $(0.007)$ & $(0.0001)$ & $(0.001)$ & $(0.007)$ & & $(0.007)$ & $(0.00003)$ & $(0.001)$ & $(0.007)$ & \\
\hline \multicolumn{11}{|l|}{$\begin{array}{l}\text { New High } \\
\text { Growth } \\
\text { Destinations }\end{array}$} \\
\hline \multirow{2}{*}{$\begin{array}{l}\text { First } \\
\text { Generation }\end{array}$} & $0.483 \sim$ & 0.004 & $0.211 \sim$ & $0.155 \sim$ & $0.113 \sim$ & $0.385 \sim$ & 0.004 & $0.181 \sim$ & 0.146 & $0.054 \sim$ \\
\hline & $(0.008)$ & $(0.00003)$ & $(0.002)$ & $(0.001)$ & $(0.007)$ & $(0.008)$ & $(0.00003)$ & $(0.001)$ & $(0.001)$ & $(0.008)$ \\
\hline \multirow{2}{*}{$\begin{array}{l}\text { Second } \\
\text { Generation }\end{array}$} & $0.378 \sim$ & 0.004 & $0.202 \sim$ & $0.172 \sim$ & - & $0.351 \sim$ & 0.002 & $0.180 \sim$ & 0.169 & - \\
\hline & $(0.014)$ & $(0.0001)$ & $(0.003)$ & $(0.014)$ & & $(0.013)$ & $(0.0001)$ & $(0.003)$ & $(0.013)$ & \\
\hline \multicolumn{11}{|l|}{$\begin{array}{l}\text { New Low- } \\
\text { Growth } \\
\text { Destinations }\end{array}$} \\
\hline \multirow[t]{2}{*}{$\begin{array}{l}\text { First } \\
\text { Generation }\end{array}$} & $\begin{array}{l}0.543 \sim \\
+\end{array}$ & 0.004 & $0.251 \sim+$ & $0.186 \sim+$ & $0.102 \sim$ & $\begin{array}{l}0.444 \sim \\
+\end{array}$ & 0.004 & $0.216 \sim+$ & $0.173 \sim+$ & $0.051 \sim$ \\
\hline & $(0.006)$ & $(0.00002)$ & $(0.002)$ & $(0.002)$ & $(0.006)$ & $(0.007)$ & $(0.00003)$ & $(0.002)$ & $(0.002)$ & $(0.008)$ \\
\hline
\end{tabular}


Table 6 Summary of non-follow-up, predicted mortality, internal migration, residual nonmatch, and predicted outmigration, CPS outgoing rotation 2001-2009 (Continued)

\begin{tabular}{ccccccccc}
\hline $\begin{array}{c}\text { Second } \\
\text { Generation }\end{array}$ & $0.412 \sim$ & 0.004 & $0.211 \sim$ & $0.197 \sim$ & - & $0.367 \sim$ & 0.002 & $0.191 \sim+$ \\
& $(0.014)$ & $(0.0001)$ & $(0.004)$ & $(0.014)$ & $(0.013)$ & $(0.0001)$ & $(0.003)$ & $(0.013)$ \\
\hline
\end{tabular}

Note: See notes to Table 2 for the definitions of destinations. ${ }^{1}$ Mortality is imputed based on NHIS-NDI data. ${ }^{2}$ Internal Migration is imputed based on the March CPS. ${ }^{3}$ Residual nonmatch figures for first-generation

Mexicans are imputed on the assumption of zero return migration (to Mexico) for second-generation Mexicans. See text for methods used for imputations. + sign indicates that the predicted terms/non-follow up rate is statistically different at the new high growth and new low-growth destination s at $95 \%$ confidence interval. $\sim$ indicates that the predicted terms/non-follow up rate for traditional and new (high or low-growth) destinations are significantly different at a $95 \%$ confidence interval. Standard errors are in parenthesis. 
longitudinal data, and predicted return migration were higher among immigrants at the newer destinations than among immigrants at the traditional destinations.

The estimated return migration rate is $5.3 \%$ for Mexican men in the traditional destinations, $11 \%$ for Mexican men at high-growth destinations and 10\% for Mexican men at low-growth destinations. The estimated outmigration rate is $1.5 \%$ for Mexican women living in the traditional destinations, $5.4 \%$ for Mexican women living in the new high growth destinations, and 5.1\% for Mexican women at the low-growth destinations ${ }^{16}$. Predicted outmigration, for both Mexican men and women, declines with time in the US (Figure 3).

Our final objective is to investigate if return migration is selective on US earnings. For this, we study the association between non-follow-up (and estimated probability of outmigration) and the real wages of Mexicans in period t-1 (Table 7). Using the sample of Mexico-born men and women in period $\mathrm{t}-1$, we run regressions with the log of the real wage in year $\mathrm{t}-1$ as the dependent variable. Estimates suggest that in the traditional destinations, the real wages of Mexico-born men in year $t-1$ who are not in the sample in year $t$ are 3.2 to $4 \%$ lower than the real wages of men who are in the sample in both years (columns 1-2). The coefficient for the interactions between non-follow-up and the new high-growth destination is negative and statistically significant, and of non-follow-up and the new low-growth destinations is close to zero and statistically insignificant.

Next we study the association between predicted outmigration between years $\mathrm{t}-1$ and $\mathrm{t}$ and real wage in $\mathrm{t}-1$ (columns 3-4). For this analysis, we predict the outmigration rate of Mexicans in two ways. First, we predict the outmigration rate of only those who were not matched in $\mathrm{t}-1$ and $\mathrm{t}$, and for the remaining individuals the outmigration rate is 0 . This prediction is based on the assumption that non-follow-up is random, which is not true for our sample given the results in columns 1 and 2 (Cameron and Trivedi 2005). Therefore, next we predict outmigration for all observations in t-1(including those who were matched in $t$ ). These estimates suggest that a 10 percentage point increase in predicted outmigration is associated with a 0.3 to $0.5 \%$ lower average wage for Mexican men at $\mathrm{t}-1$ in traditional destinations. Here too the coefficient of interaction between predicted outmigration and new-high-growth destination is negative and significant, but of predicted out-migration and new low-growth destinations is modest and statistically insignificant.

Given this evidence, our analysis thus suggests that the steeper rise in earnings of men at new high-growth destinations observed in Table 3 is at least partly due to the difference in negative selection of return migrants across destinations. In the women's analysis (columns 5-8), neither non-follow-up nor predicted outmigration has any statistically significant association with the lagged wage of Mexican women, suggesting that return migration among women is not selective on earnings. One possible reason for this could be that migration of Mexican women is more for family union compared to migration of Mexican men suggesting that women have more family support in bad economic times.

\section{Conclusions}

We use the Current Population Survey, Outgoing Rotation Group data from 2001 to 2009 to study the earnings growth and return migration of Mexican immigrants across 


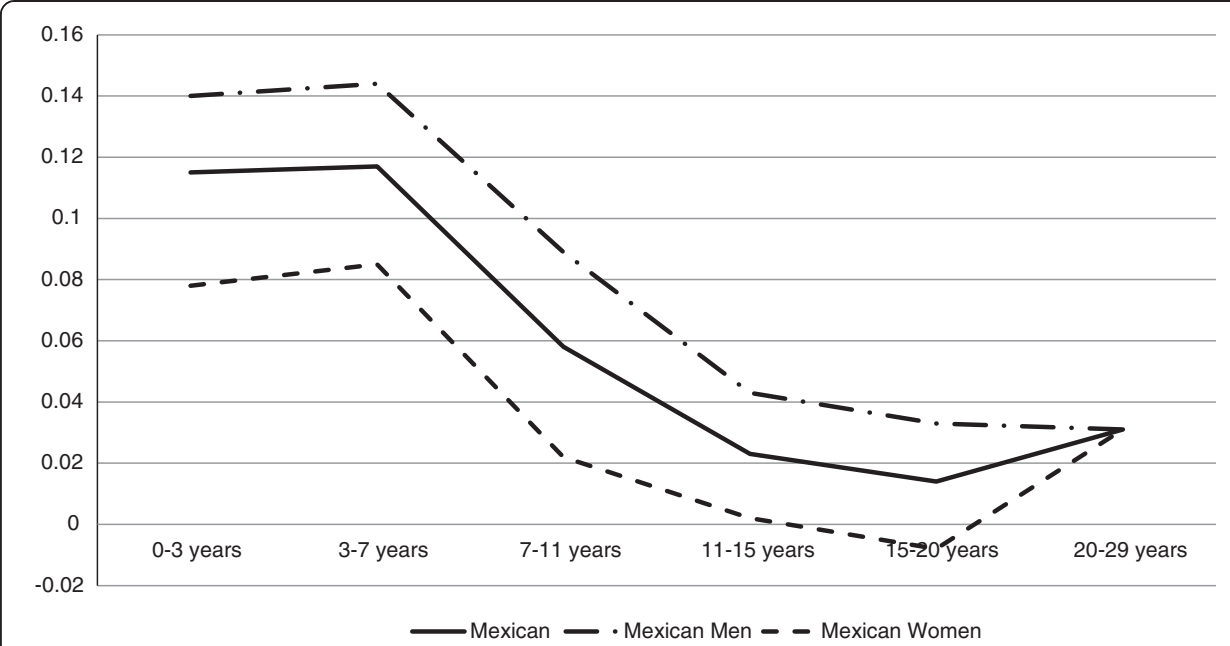

Figure 3 Predicted outmigration rate of Mexican immigrants, by years since immigration. Note: See the text for the methodology used to predict outmigration rates.

destinations. PMSAs are divided in three categories based on vintage Mexican presence in PMSA population and its growth during the 1990s.

Our analyses lead to three main findings. First, recently arrived Mexican men living in the newer destinations (high and low-growth) are two percentage points more likely to be employed and have a 4 to $5 \%$ higher average wage than recently arrived Mexican men in the traditional destinations. Mexican women at the new low growth

Table 7 Estimates of the association between log real wage in year t-1 and non-follow-up and predicted outmigration between $t$ and t-1, CPS outgoing rotation 2001-2009

\begin{tabular}{|c|c|c|c|c|c|c|c|c|}
\hline & \multicolumn{4}{|c|}{ Men } & \multicolumn{4}{|c|}{ Women } \\
\hline & 1 & 2 & 3 & 4 & 5 & 6 & 7 & 8 \\
\hline \multirow[t]{2}{*}{ Non-follow-up } & $-0.032^{* * *}$ & $-0.042^{* *}$ & & & 0.002 & 0.001 & & \\
\hline & $(0.008)$ & $(0.020)$ & & & $(0.015)$ & $(0.037)$ & & \\
\hline Non-follow-up*New High Growth & $-0.032^{*}$ & $-0.075^{*}$ & & & -0.021 & -0.051 & & \\
\hline Destination & $(0.19)$ & $(0.041)$ & & & $(0.019)$ & $(0.066)$ & & \\
\hline Non-follow-up*New Low Growth & -0.002 & -0.014 & & & -0.0002 & -0.006 & & \\
\hline Destination & $(0.012)$ & $(0.012)$ & & & $(0.023)$ & $(0.025)$ & & \\
\hline \multirow[t]{2}{*}{ Predicted Outmigration } & & & $-0.045^{* * *}$ & $-0.025^{* * *}$ & & & 0.004 & 0.003 \\
\hline & & & $(0.013)$ & $(0.007)$ & & & $(0.024)$ & $(0.016)$ \\
\hline Predicted Outmigration*New High & & & $-0.059^{*}$ & $-0.042^{* *}$ & & & -0.035 & -0.024 \\
\hline Growth Destinations & & & $(0.032)$ & $(0.020)$ & & & $(0.031)$ & $(0.020)$ \\
\hline Predicted Outmigration* New Low- & & & -0.017 & -0.018 & & & -0.004 & -0.004 \\
\hline Growth Destinations & & & $(0.012)$ & $(0.012)$ & & & $(0.022)$ & $(0.023)$ \\
\hline $\mathrm{N}$ & 14829 & 14829 & 14829 & 14829 & 6407 & 6407 & 6407 & 6407 \\
\hline
\end{tabular}

Note: See notes to Table 2 for the definitions of destinations. Samples are restricted to Mexico-born men (or women) in $\mathrm{t}-1$, who arrived in the US in 1980 or later. The dependent variable is log real wage in year $\mathrm{t}-1$. In addition to the variables listed as row headings, all regressions control for age (a dummy variable for each year of age), education, whether married, whether US citizen, industry of employment, PMSA unemployment rate, PMSA and year of observation fixed effects, age at arrival, period of arrival and years since immigration. Standard errors clustered on PMSA of residence are in parenthesis. The regressions in columns 2 and 6 also control for imputed internal migration and residual non match and these effects are allowed to differ across destinations. See text for the differences in model specifications for columns 3 and 4 (and 7 and 8 ). ${ }^{*} 0.05<p \leq 0.1,{ }^{* *} 0.01<p \leq 0.05,{ }^{* *} p \leq 0.01$. 
destinations are 6 percentage points more likely to be employed than those at the traditional or new high growth destinations but there is no statistical difference in wages across destinations. Most of the differences in labor market outcomes across destinations disappear in regressions that adjust for demographics.

We also find that recently arrived Mexican men at new destinations were about 10 percentage points (about 38\%) more likely to work in construction suggesting that the influx of Mexican men to new destinations could partly be driven by the construction boom of the past decade. It is also likely that the presence of low cost Mexican labor to some extent contributed to the construction boom.

Second, analysis based on multiple years of cross-sectional data, after controlling for a rich set of variables including period of arrival and age at arrival, shows a modest growth in Mexican immigrants' wages with time in the US: two to three decades of residency in the US is associated with a 10\% increase in the hourly wage of Mexican men and an $8 \%$ increase in the hourly wage of Mexican women. This result is somewhat similar to previous research that used data for 2000 and earlier years (see, for example, Borjas and Katz 2007). Analysis based on cross-sectional data showed different earnings trajectories across destinations. However, subsequent analysis shows differences in selective return migration across-destinations leading us to conclude that the earnings trajectories based on cross-sectional analyses are misleading.

Third, the longitudinal analysis suggests whereas first-generation Mexican men and women experienced positive annual wage growth during 2001-2009, their wage growth was generally modest in comparison to the annual growth experienced by secondgeneration Mexican men and women. We also find that Mexicans in the traditional destinations exhibited greater residential stability: internal migration, non-follow up in the longitudinal data and predicted return migration were higher among immigrants at the newer destinations than among immigrants at the traditional destinations. Predicted return migration was found to be selective on past earnings among men, but not among women. One possible explanation for this could be that migration of Mexican women is more often for family union compared to migration of Mexican men suggesting that women have more family support in bad economic times that lowers their return migration. For men, a 10 percentage point increase in predicted probability of return migration was associated with a 0.3 to $0.5 \%$ lower wage in the year prior to return. Statistical tests rejected the hypothesis that the selection pattern was the same for Mexican men in the traditional versus new high-growth destinations, underscoring the inherent weakness in estimates of earnings trajectories based on multiple crosssections of data. Further, this evidence thus suggests that studies on earnings assimilation without corresponding knowledge of selection in return migration provide an incomplete picture of Mexican immigration.

The combined evidence on earnings growth and selective return migration thus suggests that concerns about Mexicans becoming the new underclass are somewhat exaggerated since those who do poorly in the labor market often choose to return to Mexico. There is also very high residential mobility among Mexican immigrants, in particular those living in non-traditional destinations, which also points towards high level of dynamism among Mexican immigrants. The analysis thus suggests that policies that create incentives for Mexicans to restrict their cross-border mobility (e.g. stricter border controls) are likely to limit the choices of Mexicans who are not successful in 
the US economy. These immigrants may decide to extend their stay in the US, due to restrictions on cross-border flows, even when they are better off returning to Mexico.

\section{Endnotes}

${ }^{1}$ Mexican immigrants in the United States: http://pewhispanic.org/files/factsheets/ 47.pdf.

${ }^{2}$ Bohn (2009) and Kochhar et al. (2005) used more recent data, but both have a regional focus and neither has examined Mexican immigrants per se.

${ }^{3}$ Constant and Massey (2003) use longitudinal data on immigrants in Germany to study selective emigration. Duleep and Regets (1997), Duleep and Dowhan (2002), Lubotsky (2007) and Kaushal (2011) used panel data to study earnings growth in the US, but their analysis is not specific to Mexican immigrants.

${ }^{4}$ Traditionally a large proportion emigrated from Mexico's central west plateau, but during the past two decades Mexicans are emigrating from all across the country.

${ }^{5}$ There is a large literature on immigrant dispersion in the recent decades. Our focus here is Mexican immigration. Thus, for brevity, we do not discuss those studies.

${ }^{6} \mathrm{With}$ the $5 \%$ density threshold, there were 33 PMSAs in the traditional destinations, 19 PMSAs in the new high growth and 175 PMSAs in the new low growth destinations.

${ }^{7}$ We also did all analysis for 1996-2009 and results were similar to those obtained with the 2001-2009 data. We have elected to present results for the post 2000 period (for 2001-2009) because our definitions of new high-and low-growth destinations are based on 1990 and 2000 density levels.

${ }^{8}$ Arguably, the ideal measure would count only the time in the US, which for those who move back and forth is neither captured by the first reported date of arrival nor the last date of arrival. For this group, the cumulative number of years in the US and perhaps whether the years have been consecutive or interspersed that matters.

${ }^{9}$ Estimates from models that did not control for the unemployment rate or the real wage of second generation Mexicans were similar to those with the control.

${ }^{10}$ The test also fails to reject the restriction that the effects of the industry of employment are same across destinations.

${ }^{11}$ Ideally we would like to compare inter-PMSA moves, but the March CPS does not provide data on PMSA of residence last year.

${ }^{12}$ Van Hook et al. (2006) used the March CPS, whereas we are using the CPS-ORG.

${ }^{13}$ Using the March CPS data, we apply a logit regression with whether the respondent changed residences between years $\mathrm{t}-1$ and $\mathrm{t}$ as the dependent variable and the explanatory variables mentioned in the text. The coefficients on the regression variables are used to predict the internal migration for first- and second-generation Mexicans in the CPS-ORG. The March-CPS does not provide the PMSA of residence in year $t-1$ for those who moved but does provide the state of residence at $t-1$, which is controlled in this analysis.

${ }^{14}$ We make this assumption following Van Hook et al. (2006). To examine its validity, we investigated the country of birth of individuals who had returned to Mexico in the past five years in the 2000 Mexican Census and found that 14\% of all return migrants were born outside of Mexico. Some of them are likely to be US-born. Thus although a 
nontrivial number of US-born individuals return to Mexico every year, relative to Mexican-born returnees, their number is small.

${ }^{15}$ We use the second-generation Mexican sample and apply a linear regression with the imputed residual non-match as the dependent variable and the following explanatory variables: age (a dummy variable for each year of age), education $(<$ high school, high school, some college, and bachelor's degree or higher), sex, whether married, whether employed, industry of work, year of observation, and state of residence in year $\mathrm{t}-1$. The coefficients on the regression variables are used to predict residual nonmatch for first-generation Mexicans.

${ }^{16}$ Van Hook et al. (2006) estimated the out-migration rate to be $5.5 \%$ for Mexicoborn men and women.

Competing interests

The "IZA Journal of Migration" is committed to the IZA Guiding Principles of Research Integrity. The authors declare that they have observed these principles.

\section{Acknowledgements}

This paper is supported by a grant from the Russell Sage Foundation. The authors thank Robert Kaestner for his insightful comments and Adam Jentleson for preparing the GIS map.

Responsible editor: Amelie F. Constant

\section{Author details}

${ }^{1}$ School of Social Work, Columbia University, 1255 Amsterdam Avenue, New York, NY 10027, USA. ${ }^{2}$ Health Policy

Center, Institute for Health Research and Policy, UIC, 1747 West Roosevelt Road, Chicago, IL 60608, USA.

Received: 3 March 2013 Accepted: 19 June 2013

Published: 3 July 2013

\section{References}

Aguilera MB, Massey DS (2003) Social Capital and the Wages of Mexican Migrants: New Hypotheses and Tests. Soc Forces 82(2):671-701

Amuedo-Dorantes C, Mundra K (2007) Social Networks and Their Impact on the Earnings of Mexican Migrants. Demography 44(4):849-863

Blau FD, Kahn LM (2007) Gender and Assimilation among Mexican Americans. In: Borjas G (ed) Mexican Immigration to the United States. University of Chicago Press, Chicago

Bohn S (2009) "New Patterns of Immigrant Settlement in California". Public Policy Institute of California, California

Borjas G (1994) The economics of immigration. J Econ Lit 32:1667-1717

Borjas G, Katz S (2007) The Evolution of Mexican-Born Workforce in the United States. In: Borjas G (ed) Mexican Immigration to the United States. University of Chicago Press, Chicago

Cameron AC, Trivedi PK (2005) Microeconometrics: Methods and Applications. Cambridge University Press, Cambridge

Card D, Lewis EG (2007) The Diffusion of Mexican Immigrants during the 1990s: Explanations and Impacts. In: Borjas G (ed) Mexican Immigration to the United States. University of Chicago Press, Chicago

Constant A, Massey DS (2003) Self-Selection, Earnings and Out-Migration: A Longitudinal Study of Immigrants. J Popul Econ 16(4):631-653

Duleep HO, Dowhan DJ (2002) Insights From Longitudinal Data on the Earnings Growth of US Foreign-Born Men. Demography 39(3):485-506

Duleep HO, Regets M (1997) Measuring Immigrant Wage Growth Using March CPS Files. Demography 34:239-249

Duncan B, Hotz VJ, Trejo SJ (2006) "Hispanics in the US Labor Market.". In: Hispanics and the Future of America, Tienda, M., and F. Mitchellth edn. National Academies Press, Washington, DC

Kaushal N (2011) "Earning Trajectories of Highly-Educated Immigrants: Does Place of Education Matter?". Ind Labor Relat Rev 64(2):6, article

Kaushal N, Kaestner R (2010) Geographic Dispersion and Internal Migration oflmmigrants. Front Econ Global 8:137-173

Kochhar R, Suro R, Tafoya S (2005) The New Latino South: The Context and Consequences of Rapid Population Growth. Washington D.C, The Pew Hispanic Center

Lazear EP (2007) Mexican assimilation in the United States. In: Borjas GJ (ed) Mexican immigration to the United States. University of Chicago Press, Chicago, pp 107-122

Lubotsky D (2007) Chutes or Ladders? A Longitudinal Analysis of Immigrant Earnings. J Polit Econ 115(5):820-867

Mason KO, Mason WM, Winsborough HH, Poole WK (1973) Some methodological issues in cohort analysis of archival data. Am Sociol Rev 38(2):242-258

Massey DS (1987) Understanding Mexican Migration to the United States. Am J Sociol 92:1372-1403

Massey D (ed) (2008) New Faces in New Places: the Changing Geography of American Immigration. Russell Sage, New York

Munshi K (2003) Networks in the Modem Economy: Mexican Migrants in the US Labor Market. Q J Econ 118:549-599

Passel J, Cohn D (2009) Mexican Immigrants: How Many Come? How Many Leave? Pew Hispanic Center Report, Washington DC 
Ramirez, Roberto R. 2004. "We the People: Hispanics in the United States". Census (2000) Special Report. US Department of Commerce Economics and Statistics. Administration, US Census Bureau

Rumbaut RG (2006) "The Making of a People". In Hispanics and the Future of America, eds. Tienda, M., and F. Mitchell. National Academies Press, Washington, DC

Redstone I, Massey DS (2004) Coming to Stay: Question on Year of arrival. Demography 41(4):721-738

Van Hook J, Passel J, Bean FD, Zhang W (2006) Foreign-born Emigration: A New Approach and Estimates Based on Matched CPS Files. Demography 43:361-382

Zhou M, Logan JR (1989) Returns on Human Capital in Ethnic Enclaves: New York City's Chinatown. Am Sociol Rev 54:809-820

doi:10.1186/2193-9039-2-11

Cite this article as: Kaushal and Shang: Earnings growth of Mexican immigrants: new versus traditional

destinations. IZA Journal of Migration 2013 2:11.

Submit your manuscript to a SpringerOpen ${ }^{\circ}$ journal and benefit from:

- Convenient online submission

- Rigorous peer review

- Immediate publication on acceptance

- Open access: articles freely available online

- High visibility within the field

- Retaining the copyright to your article

Submit your next manuscript at $>$ springeropen.com 